\title{
Factors Affecting Earnings Response Confficient (ERC) in Manufacturing Companies Listed on BEI
}

\author{
KATARINA DYAH KRISTANTI \\ LUCIANA SPICA ALMILIA \\ STIE Perbanas Surabaya
}

\begin{abstract}
This research aims to analyze which factors significantly influence Earnings Response Coefficient (ERC). The sample of this research is including manufacturing companies listed in Indonesia Stock Exchange between period 2012-2016. The sample is drawn using a purposive sampling method. There are 280 samples in total that are examined to conduct the study. Multiple regression analysis is used in this research to examine the hypotheses. Independent variables used in this research are earning persistence, profitability, leverage, growth opportunity, firm size, audit quality, CSR disclosure, and conservatism. The result of this research suggests that profitability and firm size have a significant and positive influence on Earning Response Coefficient. Result also shows earning persistence, and growth opportunity has a significant and negative influence on Earning Response Coefficient. Meanwhile, leverage, audit quality, CSR disclosure, and conservatism do not significantly influence the Earning Response Coefficient.
\end{abstract}

Keywords: Earning Response Coefficient; ERC; earning persistence; profitability; leverage; growth opportunity; size; audit quality; conservatism

Abstrak: Penelitian ini bertujuan untuk menganalisis faktor mana yang secara signifikan mempengaruhi Earnings Response Coefficient (ERC). Sampel penelitian ini termasuk perusahaan manufaktur yang terdaftar di Bursa Efek Indonesia antara periode 2012-2016. Sampel diambil dengan menggunakan metode purposive sampling. Ada 280 sampel total yang diperiksa untuk melakukan penelitian. Analisis regresi berganda digunakan dalam penelitian ini untuk menguji hipotesis. Variabel independen yang digunakan dalam penelitian ini adalah ketekunan produktif, profitabilitas, leverage, peluang pertumbuhan, ukuran perusahaan, kualitas audit, pengungkapan CSR, dan konservatisme. Hasil penelitian ini menunjukkan bahwa profitabilitas dan ukuran perusahaan berpengaruh signifikan dan positif terhadap Earning Response Coefficient. Hasil juga menunjukkan persistensi pendapatan dan peluang pertumbuhan memiliki pengaruh yang signifikan dan negatif terhadap Koefisien Respon Pendapatan. Sementara itu leverage, kualitas audit, pengungkapan

*Corresponding author: lucy@ perbanas.ac.id 

CSR, dan konservatisme tidak secara signifikan mempengaruhi Koefisien Respons Pendapatan.

Keywords: Earning Response Coefficient; ERC; earning persistence; profitability; leverage; growth opportunity; size; audit quality; conservatism

\section{Introduction}

The capital market plays an essential role in supporting the development of a country's economy. If a large amount of cash flow is directed to the capital market, this can encourage a country's economy to be more productive. The Indonesian capital market currently occupies the fourth position as the largest capital market in the world and second in Asia. Along with the increasing capital market in Indonesia, the need for information on financial statements has become critical. Information on financial statements, especially earnings information, is one of the means for investors to make decisions. Therefore this information regarding earnings is the most responded by investors.

Earnings Response Coefficient (ERC) is one measure that can be used to measure the relationship between earnings and stock returns (Anggreni, 2016). The efficient market theory explains that the price of securities will quickly reflect new information on the market. Based on this theory, the information on profit increase and decrease should also be in line with the stock price at the time of the earnings announcement. The phenomenon that occurs shows that the earnings information is not always in line with stock returns, which are a proxy of investor response. In Figure 1, it can be seen that the profits of SMGR companies experienced a decline in profits from 2014 to 2015 and then experienced an increase in profits from 2015 to 2016. The decline in profit of the SMGR company was followed by a decrease in the price of SMGR shares during the announcement of 2015 earnings in Figure 2. However, the increase in profits from 2015 to 2016 was followed by a decline in share prices 
Figure 1

THE GRAPHIC OF MANUFACTURING COMPANY PROFIT

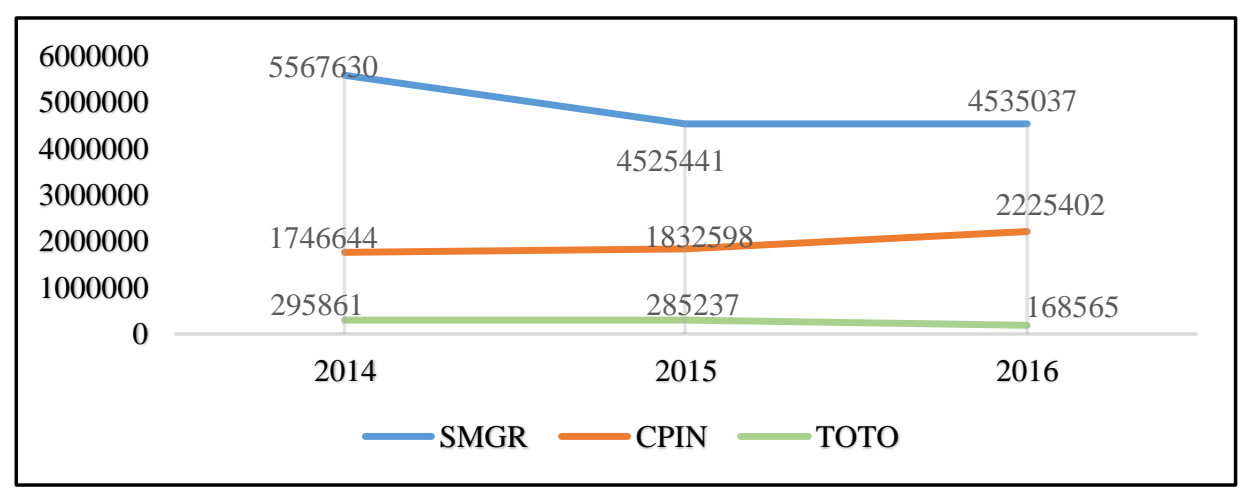

Source: IDX, processed

At CPIN companies, there was an increase in profits from 2014 to 2015 (Figure 1). The increase in profits was followed by an increase in share prices (Figure 2). In the following year, CPIN's corporate profits increased again (Figure 1), but the increase in profits was not followed by an increase in share prices at the time of earnings announcements (Figure 2). The TOTO company experienced a decline in profit from 2014 to 2015 (Figure 1), but its share price increased (Figure 2). Then in the following year, TOTO's profit declined again, and this was also followed by a decline in share prices at the time of the 2016 earnings announcement (Figure 2). Data from this phenomenon shows that investor responses are not always in line with company earnings information.

Several factors affect the earnings response coefficient. One of them is earnings persistence. Earnings persistence is the company's ability to maintain its profits. The company's ability to keep profits from year to year is responded by investors as good news when the company reports its profits (Fitria, 2013). Some previous research conducted by Anggreni (2014), Zakaria (2013), and Fitria (2013) revealed that earnings persistence had a positive effect on ERC. However, some other researchers, namely Gunawan (2015) and Mashayekhi (2016), found that earnings persistence did not have a significant effect on ERC. 
Figure 2

THE GRAPHIC OF MANUFACTURE COMPANY'S SHARE PRICES

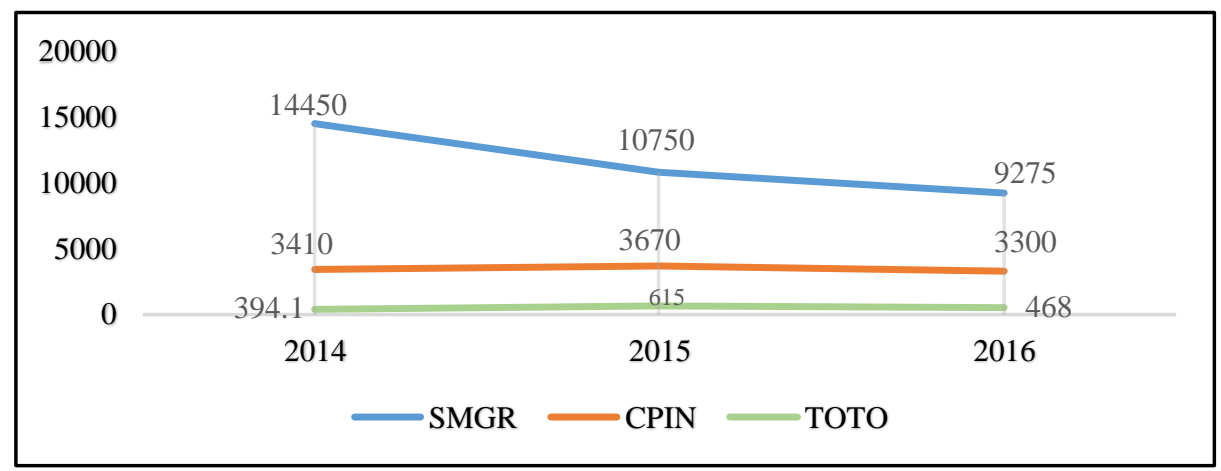

Source: IDX, processed

Companies with good financial performance can be seen through their profitability ratios. If the company's financial performance is getting better, the greater the investor's response to the profits generated by the company is. The results of previous studies conducted by Hasanzade (2013) and I Gusti (2016) showed that profitability has a significant and positive influence on the earnings response coefficient. This is contrary to the research on the relationship of profitability to earnings response coefficients conducted by Vinola (2016) and Gunawan (2015).

Capital structure is a ratio that shows the level of corporate debt compared to capital. Companies with high leverage will be responded negatively by investors because the company prefers creditors over shareholders. This is in line with the research of Vinola (2016) and An (2015), who found that capital structure has a significant and negative influence on the earnings response coefficient. Another study conducted by Gunawan (2015), Hasanzade (2013), and Fitria (2013) revealed there was no significant effect of capital structure on earnings response coefficients. Research conducted by Anggreni (2014) found that capital structure has a significant and positive influence on the earnings response coefficient.

Growth Opportunity reflects the potential of investment to grow significantly. Companies with high growth opportunities will tend to have high ERC because of the opportunity to develop investments. Researches conducted by Hasanzade (2013) and 
Zakaria (2013) can prove that growth opportunity has a significant and positive influence on ERC. However, Gunawan (2015) and Rahmat (2016) stated that growth opportunity does not have a significant effect on ERC.

The size of the company is also believed to be able to provide different investor responses. Companies with large size will tend to get more trust from investors and get a better response because they are considered more capable of improving the quality of performance. This is in line with research conducted by I Gusti (2016), Mashayekhi (2016), and Zakaria (2013), saying that company size has a positive and significant influence on ERC. But the results of research conducted by Gunawan (2015), Zeidi (2014), and Fitria (2013) found that company size had no significant effect on ERC. In addition, research conducted by Anggreni (2014) found that company size had a positive effect on ERC in Asian companies, but had a negative effect on companies in Europe.

Quality audits will provide reliable financial reports for investors. The better the audit quality of a company, the better the investor's response is. Fitria (2013), Okolie (2014), Heydari (2015), and Zakaria (2013) stated that audit quality has a significant effect on ERC, whereas Gunawan (2015) stated that audit quality has no significant effect on ERC. Du (2014) found that the effect of auditor's reputation on ERC was more significant in American companies than in Chinese companies.

CSR disclosure is one way of communicating corporate responsibility to society and the environment. CSR disclosure is expected to increase earnings response because it provides the added value of information to investors. The results of a study conducted by Vinola (2016) show that CSR disclosure has a negative effect on the earnings response coefficient. Meanwhile, Dian's (2015) research did not find the effect of CSR disclosure on earnings response coefficients.

Another factor that can affect ERC is conservatism. Conservatism is an accounting principle that measures profit or assets with caution. The precautionary principle can lead to different market responses on earnings information. Arna's research (2016) found that conservatism has a positive effect on earnings response coefficients. Meanwhile, research from Zeidi (2014) found conservatism has a 
negative effect on earnings response coefficients.

Based on the phenomena related to different investor responses and the inconsistency of the results of previous research, the researchers decided to conduct research related to the influence of factors such as earnings persistence, profitability, capital structure, growth opportunity, company size, audit quality, CSR disclosure, and conservatism on the earnings response coefficient.

\section{Theoretical Framework and Hypothesis}

\subsection{Capital Market Efficiency}

Research on Earnings Response Coefficient relates to efficient capital market theory. According to Scott (2012: 110), an efficient capital market theory states that the price of securities in the market has reflected all the information about those securities. This study examines the theory of efficient capital markets because ERC shows how much financial information influence is reflected in the price of securities. In this theory, the capital market is divided into three groups, namely, a strong, half strong, and weak capital market. The stronger the capital market, the better the stock price in representing available financial information.

\subsection{Signal Theory}

Bhattacharya (1979) suggested that signaling theory arose because companies are encouraged to provide information to external parties. Signal theory stated how companies provide information that can provide signals to users of financial statements (Vinola, 2016). Information in financial statements is information that determines investor response. Information given by the company to investors will give a positive signal or a negative signal.

Research on ERC is related to signaling theory. This is because the signal theory explains how the investor will respond or provide a response to the information disclosed by the company to users of financial statements. The presence of a positive signal or a negative signal will result in changes in the company's stock price. 


\subsection{Earnings Response Coefficient}

Earnings informativeness can be seen by looking at how big the investor's response to the company's accounting earnings information. ERC is one of the proxies for measuring earnings informativeness. Scott (2012: 163) defined ERC as a measure of abnormal security returns in response to the unexpected component of earnings reported by the company that issued the security. Therefore, ERC is measured by the magnitude of the regression coefficient slope between abnormal return and unexpected earnings.

\subsection{Effect of Profit Persistence on ERC}

High-profit persistence shows that the company is getting better at maintaining its profits. Investors will be interested in companies that can maintain their profits from year to year. So, when reporting the earnings, companies with high earnings persistence will be responded very well by investors.

In connection with the theory of capital market efficiency, the price of a security will be able to reflect the information contained in the security. In this study, earnings persistence is a company's financial information where ups and downs of earnings persistence can be seen in stock prices. The value of the security's price is influenced by investors' response to earnings persistence information at the time of earnings announcements. Some previous research conducted by Anggreni (2014), Zakaria (2013), and Fitria (2013) supported the statement that said earnings persistence has a positive effect on earnings response coefficients. However, some other researchers, namely Gunawan (2015) and Mashayekhi (2016), found that earnings persistence did not have a significant effect on ERC. Based on the description, the hypothesis can be formulated as follows:

H1. Earnings persistence has a significant effect on ERC.

\subsection{Effect of Profitability on ERCE}

Profitability shows financial performance in generating profits. If the company's financial performance is getting better, the greater the investor's response to the profits 
generated by the company is. Therefore companies with high profitability will have a higher ERC.

The capital market is said to be efficient when the price of a security can reflect the information contained in that security. In this study, profitability is the company's financial information, where the value of profitability can affect stock prices through investor response to earnings information. So the increase in profitability can have a positive effect on ERC.

Previous research conducted by Hasanzade (2013) and I Gusti Ayu (2016) supported the statement saying that profitability has a significant and positive influence on ERC. This is contrary to research conducted by Vinola (2016) and Gunawan (2015), which cannot prove the effect of profitability on ERC. Based on the description, the hypothesis can be formulated as follows:

H2. Profitability has a significant effect on ERC.

\subsection{Effect of Capital Structure on ERC}

The theory of capital market efficiency can explain the effect of capital structure on ERC. In this study, capital structure is the financial information of a company in which the size of the debt value can affect stock prices through investor response. Companies with high leverage will prioritize their creditors. Investors become not interested because more profits will be channeled to creditors considering that the company is mostly funded through debt. So, when there is an earnings announcement, companies with higher levels of leverage will be responded negatively by investors because of the emergence of risk on debt.

This is in line with the researches of Vinola (2016) and An (2015), who found that capital structure has a significant and negative influence on the earnings response coefficient. However, in other studies conducted by Gunawan (2015), Hasanzade (2013), and Fitria (2013) revealed no significant effect of capital structure on the earnings response coefficient. Research conducted by Anggreni (2014) found that capital structure has a significant and positive influence on the earnings response coefficient. Based on the description, the hypothesis can be formulated as follows: 
H3. Capital Structure has a significant effect on ERC.

\subsection{Effect of Growth Opportunity on ERC}

The effect of growing opportunity on ERC is related to signaling theory. High growth opportunities from an investment will give a positive signal to investors. Therefore high growth opportunities will be responded to as good news at the time of earnings announcements. So that this positive signal for good news shows a high investor response to the announced earnings.

Research conducted by Hasanzade (2013) and Zakaria (2013) can prove that growth opportunity has a significant and positive influence on the Earnings Response Coefficient. However, Gunawan (2015) and Rahmat (2016) stated that growth opportunity does not have a significant effect on the Earnings Response Coefficient. Based on the description, the hypothesis can be formulated as follows:

H4. Growth Opportunity has a significant effect on ERC.

\subsection{Effect of Company Size on ERC}

In connection with the theory of capital market efficiency, the size of the company will show the company's information related to business activities. For investors, then it will be reflected in the price of securities. Large companies are generally easier to improve their performance. Therefore, investors will be more confident to invest their capital in large companies rather than small companies. Likewise, at the time of earnings announcements, large companies will get more response from investors than smaller companies.

Research conducted by I Gusti (2016), Mashayekhi (2016), and Zakaria (2013) stated that company size has a positive and significant effect on earnings response coefficients. But the results of research conducted by Gunawan (2015), Zeidi (2014), and Fitria (2013) found that company size does not have a significant effect on the earnings response coefficient. Also, research conducted by Anggreni (2014) found that company size has a positive effect on earnings response coefficients in Asian 
companies, but has a negative effect on companies in Europe. Based on the description, the hypothesis can be formulated as follows:

H5. Company size has a significant effect on ERC.

\subsection{Effect of Audit Quality on ERC}

Audit quality is the company's information that can lead to different investor responses. The effect of audit quality on ERC can be explained by signaling theory. Quality audits are information that gives a positive signal so that investor response increases as investor confidence increases.

Research conducted by Fitria (2013), Okolie (2014), Heydari (2015), and Zakaria (2013) stated that audit quality has a significant effect on the earnings response coefficient. Whereas Gunawan (2015) stated that audit quality does not significantly influence the earnings response coefficient. Based on the description, the hypothesis can be formulated as follows:

H6. Audit quality has a significant effect on ERC.

\subsection{Effects of CSR Disclosures on ERC}

The effect of CSR disclosure on ERC can be explained through capital market efficiency theory. Capital market efficiency theory explains that information related to securities will be reflected in the price of securities. In this case, CSR disclosure is the company's information that provides added value and will affect investor response. Therefore the added value of this CSR information will be reflected in the price of the security.

The results of a study conducted by Vinola (2016) showed that CSR disclosure has a negative effect on the earnings response coefficient. Meanwhile, Dian's (2015) research did not find the effect of CSR disclosure on earnings response coefficients. Based on the description, the hypothesis can be formulated as follows:

H7. CSR disclosure has a significant effect on ERC. 


\subsection{Effects of Conservatism on ERC}

The effect of conservatism can be explained through the signaling theory. The conservatism principle will give a positive signal to investors. This is because the principle can anticipate the possibility of investors making wrong decisions because there is an exaggerated profit value. The positive investor signals will be reflected in the increase in investor response at the time of earnings announcements.

Arna's research (2016) found that conservatism has a positive effect on earnings response coefficients. Meanwhile, research from Zeidi (2014) found that conservatism has a negative effect on the earnings response coefficient. Based on the description, the hypothesis can be formulated as follows:

H8. Conservatism has a significant effect on ERC.

The framework of thought in this study is as follows:

Figure 3

FRAMEWORK OF THOUGHT

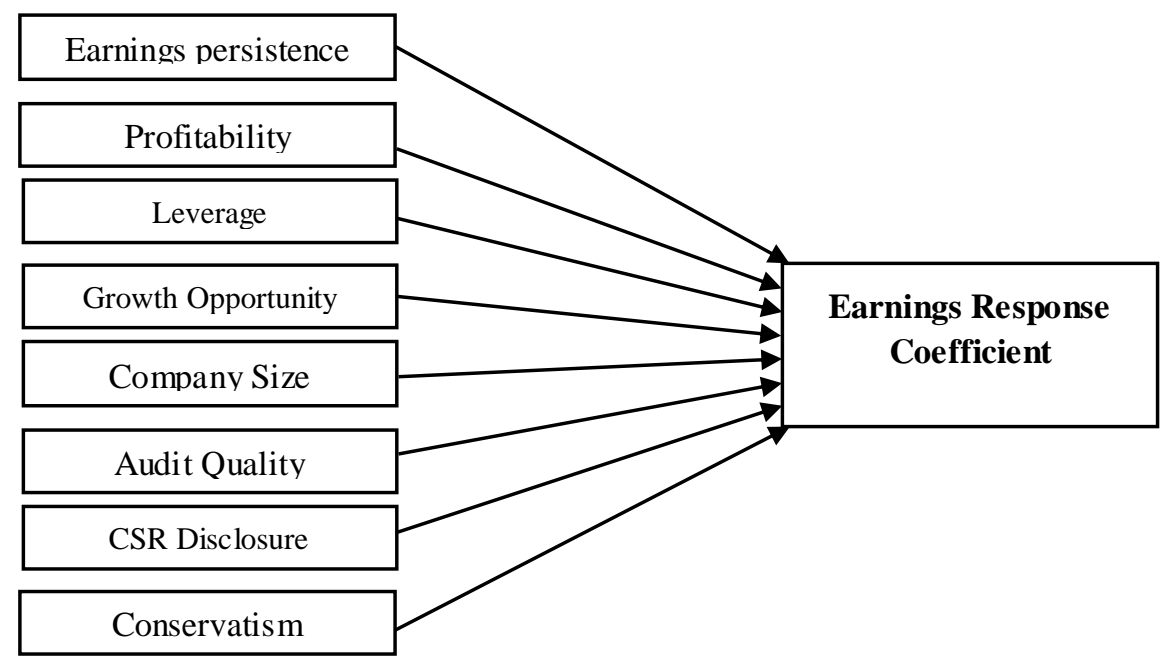

\section{Research Methodology}

\subsection{Sample Selection}

The research population was manufacturing companies in Indonesia. The sample of this research was manufacturing companies listed on the Indonesia Stock Exchange 
(IDX) in 2012-2016. The amount of data in this study was 280 data. The sampling technique used a purposive sampling technique. Sample criteria in this study included: (1) Manufacturing sector companies listed on the IDX in 2012-2016, (2) Companies whose shares were actively traded on the IDX during 2012-2016, (3) Company that presented financial statements in rupiah currency, (4) Company that had complete data needed in this study.

\subsection{Research Data}

The data used is secondary data. The data collection method in this study used documentation method, in which data collected from the financial statements of manufacturing companies which were accessed from the official website of IDX, namely idx.co.id and daily stock price data from Yahoo Finance.

\subsection{Research Variable}

The dependent variable in this study was ERC. The independent variables used in this study were earnings persistence, profitability, leverage, growth opportunities, company size, audit quality, CSR disclosure, and conservatism.

\subsection{Definition of Operational Variables}

\subsubsection{Earnings Response Coefficient}

Earnings Response Coefficient is a measure of earnings informativeness seen through the proxy of stock prices and proxies of accounting earnings to explain how the market responds to earnings information (Anggreni, 2014). ERC is calculated by a regression between abnormal returns and unexpected earnings.

$\operatorname{CAR}_{i, t}(-5,+5)=a+b 1 E_{i, t}+e$

Notes:

$\mathrm{CAR}_{\mathrm{i}, \mathrm{t}}=$ Cumulative Abnormal Return of the company $\mathrm{i}$ in the quarter $\mathrm{t}$

$\mathrm{UE}_{\mathrm{i}, \mathrm{t}}=$ Unexpected Earnings of the company $\mathrm{i}$ in the quarter $\mathrm{t}$

b1 = Regression Coefficient $($ ERC)

\subsubsection{Earnings Persistence}

Earnings persistence is a measure of how a company can maintain its profits. The quarterly earnings regression coefficient measures earnings persistence. 
$X_{i, t}=a+b_{i, t} X_{i, t-1}+e$

Notes:

$\mathrm{X}_{\mathrm{i}, \mathrm{t}}=$ The profit of company $\mathrm{i}$ in the quarter $\mathrm{t}$

$\mathrm{X}_{\mathrm{i}, \mathrm{t}-1}=$ The profit of company $\mathrm{i}$ in the previous quarter $(\mathrm{t}-1)$

\subsubsection{Profitability}

Profitability explains the company's ability to generate profits. Profitability calculations are:

ROA $=\frac{\text { Net profit }}{\text { Total Aset }}$

\subsubsection{Capital Structure}

Capital structure is defined as a ratio that shows the portion of a company's funding sources through debt or shares. In this study, capital structure is measured using a leverage ratio, namely, DER (Debt to Equity Ratio).

$\mathrm{DER}=\frac{\text { Total debt }}{\text { Total equity }}$

\subsubsection{Growth Opportunity}

Growth Opportunity is a measure that reflects the growth potential of an investment. Growth Opportunity is calculated through the PBV ratio as follows:

$\mathrm{PBV}=\frac{\text { Stock closing price }}{\text { The book value of shares }}$

\subsubsection{Company Size}

Company size is a scale that shows the size of a company. The following formula measures company size:

$\mathrm{SIZE}=\mathrm{Ln}($ total asset$)$

\subsubsection{Audit Quality}

Audit quality is a measure of the auditor's ability to reduce disruption and bias in providing accounting data (Okolie, 2014). Audit quality in this study was measured by the auditor's reputation. Measurement of auditor reputation in this study is the same as 
Luciana conducts that (2004), namely by rating auditors based on the number of clients audited. The auditor rating category is assumed to be an underwriter ranking by the Johnson-Miller's measure. The ranking is done by dividing auditors into three ratings based on the auditor's highest number of clients.

\subsubsection{CSR Disclosure}

CSR disclosure is the communication of corporate activity responsibilities in environmental and community aspects. CSR disclosure is based on the Global Reporting Initiative (GRI) G4 guidelines with a total of 91 items. The CSR disclosure formula is:

CSRDI $=\frac{\text { number of items disclosed }}{\text { total indicator }}$

\subsubsection{Conservatism}

Conservatism is an accounting principle that recognizes the lower value of earnings or assets and the higher value of obligations or expenses.

Conservatism $=\frac{\text { Net profit before depreciation }}{\text { Operating cash flow }}$

\subsection{Analysis Tool}

Data analysis techniques were done using multiple linear regression analysis. Data analysis conducted in this study included descriptive statistical analysis, classic assumptions test (normality test, multicollinearity, autocorrelation, and heteroscedasticity), model feasibility analysis ( $F$ test), coefficient of determination analysis $\left(\mathrm{R}^{2}\right)$, and $\mathrm{t}$-test analysis.

The equation model in this study is:

$\mathrm{ERC}=\alpha+\beta 1 \mathrm{PL}+\beta 2 \mathrm{ROA}+\beta 3 \mathrm{DER}+\beta 4 \mathrm{PBV}+\beta 5 \mathrm{SIZE}+\beta 6 \mathrm{AQ}+\beta 7 \mathrm{CSR}+\beta 8$

$$
\mathrm{KSRV}+\mathrm{e}
$$

Notes:

ERC $=$ Earnings Response Coefficient

$\alpha=$ Constant

$\beta_{1-} \beta_{8}=$ Regression coefficient 
$\mathrm{PL} \quad=$ Earnings persistence

$\mathrm{ROA}=$ Return on Asset Ratio

DER = Debt to Equity Ratio

$\mathrm{PBV}=$ Growth Opportunity

SIZE = Company Size

$\mathrm{AQ} \quad=$ Audity Quality

CSR = CSR Disclosure

$\mathrm{KSRV}=$ Conservatism

$\mathrm{e} \quad=$ Error

\section{Data Analysis and Discussion}

\subsection{Descriptive Test}

As can be seen in Table 1, the maximum and minimum ERC values of the entire sample are 4.24 and -4.31 . The existence of a negative sign on the value of ERC indicates that the relationship between earnings information and investor response is not unidirectional, meaning that an increase in earnings is followed by a decrease in investor response, and vice versa. The overall average ERC value is 0.07. There are $55 \%$ of samples that have ERC values below the average of the total observations. The lower the ERC, the lower the investor response to earnings information announced by the company is.

Tabel 1

Descriptive Analysis Result

\begin{tabular}{|l|c|c|c|c|}
\hline Variable & $\mathrm{N}$ & Minimum & Maximum & Mean \\
\hline ERC & 280 & $-4,308$ & 4,238 & 0,066 \\
\hline PL & 280 & $-4,354$ & 4,498 & 0,0395 \\
\hline ROA & 280 & $-0,547$ & 0,358 & 0,055 \\
\hline DER & 280 & $-21,235$ & 16,588 & 1,112 \\
\hline PBV & 280 & $-4,320$ & 23,856 & 1,932 \\
\hline SIZE & 280 & $\begin{array}{c}\text { Rp 95.272 } \\
\text { (million) }\end{array}$ & $\begin{array}{c}\text { Rp 262.166.260 } \\
\text { (million) }\end{array}$ & $\begin{array}{c}\text { Rp 2.114.839 } \\
\text { (million) }\end{array}$ \\
\hline CSR & 280 & 0,00 & 0,516 & 0,122 \\
\hline KSRV & 280 & $-106,123$ & 24,998 & 0,781 \\
\hline
\end{tabular}

Source:Processed data 
The maximum and minimum earnings persistence values of the whole sample are 4.50 and -4.35 . The average value of earnings persistence is 0.04 . Of the total observations of 280 data, 178 samples had below-average earnings persistence.

The maximum and minimum profitability values of the entire sample are 0.36 and -0.55 . The average ROA is 0.05 . From a total of 280 observations, 135 samples have above-average profitability values. This means that the 135 sample companies have above-average financial performance.

The maximum and minimum capital structure values of the entire sample are 16.59 and -21.23 . The average overall DER value is 1.11. From a total of 280 data observations, $63 \%$ of the sample has a DER value below the average. The lower the DER value, the company is said to be good because the capital composition is higher than the debt composition.

The maximum and minimum PBV values of the entire sample are 25.86 and 4.32. A negative sign is caused by the book value of the company's equity being in a negative condition. This can happen if the company continues to experience losses. The average PBV value is 1.93 . From a total of 280 observations, 85 samples have PBV values above the average. Meanwhile, the remaining 195 samples have PBV below the average.

The maximum and minimum SIZE values of the entire sample are IDR $262,166,260,371,891$ and $95,271,828,948$. The average total value of total assets in this study is $\operatorname{Rp} 2,114,839,417,474$. From a total of 280 data observations, 117 samples have SIZE values above the average. Meanwhile, the remaining 163 samples have SIZE below the average.

The highest quality audit rating of manufacturing companies from 2012 to 2016 is ranked 1. Ranking 1 is given to companies that receive the lowest audit quality. The data shows that many manufacturing companies that have low audit quality are 192 samples or $69 \%$ of the total research sample.

The maximum and minimum CSR values are 0.52 and 0.00 . The average CSR is 0.12. The low average of CSR shows the low CSR disclosure made by manufacturing companies. Of the total observations of 280 data, 173 samples have CSR below the 
average. This shows that most of the samples in this study have not yet widely disclosed CSR.

The maximum and minimum conservatism values are 25.00 and -106.12 . The average value of the overall conservatism is 0.78 . From a total of 280 data observations, 173 samples have conservatism values above the average. Meanwhile, the remaining 107 samples have conservatism below the average.

\subsection{Classic Assumption Test}

\subsubsection{Normality}

The Kolmogorov-smirnov value before the outlier is 5.633, and the significance value is 0,000 . The significance level is less than 0.05 , so the residuals are not normally distributed. Then the researcher removed the outlier data. Kolmogorovsmirnov value after the outlier is 1.257 , and the significance is 0.085 . The significance level is more than 0.05 (0.085>0.05), then $\mathrm{H}_{0}$ is accepted. It can be concluded that the residuals are normally distributed.

\subsubsection{Multicollinearity}

A multicollinearity test is used to test whether the research model found a correlation between independent variables. From the results of the analysis, no VIF value exceeds ten, and the tolerance value is also above 0.1 for all variables. It can be concluded that there is no multicollinearity in this study.

\subsubsection{Autocorrelation}

The number of samples (n) is 280 and 8 independent variables $(\mathrm{k}=8)$, and the significance is 0.05 , so the $\mathrm{dL}$ and $\mathrm{dU}$ values are 1.75 and 1.86 , respectively. The Durbin Watson test results of 2.11 are greater than the upper limit of dU (1.86) and less than 4-dU (2.14). The DW value is between dU and 4-dU $(1.86<2.114<2.14)$. This research model is free from autocorrelation. 


\subsubsection{Heteroscedasticity}

Heteroscedasticity test is used to test whether there is an unequal variance from the residuals of one observation to another from the research model. The Glejser Test performs heteroscedasticity. Significance values for all independent variables on absolute residuals are greater than 0.05 . It can be concluded that there is no heteroscedasticity in this study.

Tabel 2

Multiple Linear Regression Analysis Result

\begin{tabular}{|l|c|c|c|c|}
\hline \multicolumn{1}{|c|}{ Variable } & $\begin{array}{c}\text { Regression } \\
\text { Coefficient }\end{array}$ & Std Error & $\mathrm{t}$ & Significance \\
\hline (Constant) & $-3,004$ & 0,884 & $-3,396$ & 0,001 \\
\hline PL & $-0,139$ & 0,064 & $-2,178$ & 0,030 \\
\hline ROA & 1,249 & 0,552 & 2,262 & 0,025 \\
\hline DER & 0,024 & 0,019 & 1,287 & 0,199 \\
\hline PBV & $-0,124$ & 0,019 & $-6,520$ & 0,000 \\
\hline SIZE & 0,117 & 0,033 & 3,567 & 0,000 \\
\hline AQ & $-0,061$ & 0,062 & $-0,982$ & 0,327 \\
\hline CSR & $-0,222$ & 0,726 & $-0,306$ & 0,760 \\
\hline KSRV & 0,000 & 0,006 & $-0,115$ & 0,908 \\
\hline Adjusted R ${ }^{2}$ & & \multicolumn{3}{|c|}{0,151} \\
\hline F & & \multicolumn{3}{|c|}{0,000} \\
\hline Sig. F
\end{tabular}

Source :Processed data

\subsection{Analysis of Result and Discussion}

In Table 2, it can be seen that the calculated $F$ value indicates the value of 7.214 and a significance of 0.000 . The level of significance is less than $0.05(0,000<0.05)$. The regression model is said to be fit, and there is an influence of one of the independent variables on the Earnings Response Coefficient variable.

Based on the test results of the coefficient of determination, it can be seen that the adjusted $\mathrm{R}^{2}$ value is 0.151 (Table 2 ). This means that the ability of the research model to explain the dependent variable (ERC) is $15.1 \%$.

\subsection{Effect of Earnings Persistence on ERC}

The test results show the persistence of earnings has a significant effect on ERC $\left(\mathrm{H}_{1}\right.$ accepted). In Table 3, the average PL value for ERC below the average has a 
higher value than the average PL value for ERC above the average. This shows the opposite direction between earnings persistence and ERC.

Tabel 3

Descriptive Value Average

\begin{tabular}{|l|c|c|c|c|c|c|c|c|c|}
\hline & $\mathrm{N}$ & PL & ROA & DER & PBV & SIZE & AQ & CSR & KSRV \\
\hline ERC below the average & 155 & 0,12 & 0,05 & 0,97 & 2,32 & 28,34 & 1,55 & 0,12 & 0,48 \\
\hline ERC above the average & 125 & $-0,06$ & 0,06 & 1,29 & 1,45 & 28,43 & 1,42 & 0,12 & 1,15 \\
\hline
\end{tabular}

Meanwhile, the difference between the average PL for ERCs above and below the average is relatively large enough to indicate that earnings persistence has a significant effect on ERC. According to capital market efficiency theory, the price of securities, which is a reflection of investor responses, will increase with the presence of good company earnings quality information. Conversely, when a company is unable to show high earnings persistence value, investors will respond negatively, resulting in a decline in shares at the time of earnings announcements. If this happens, the decline in earnings persistence value will be followed by a decrease in the earnings response coefficient. However, although the results of this study indicate that earnings persistence has a significant influence, the direction of the effect of earnings persistence on ERC is not following capital market efficiency theory.

Previous studies do not support the results of this study. Research conducted by Anggreni (2014), Zakaria (2013), and Fitria (2013) found that earnings persistence has a significant positive effect on earnings response coefficients. Meanwhile, the results of this study indicate a significant negative effect on earnings persistence on ERC. These results are also not in line with research conducted by Gunawan (2015) and Mashayekhi (2016), who found that earnings persistence does not have a significant effect on the Earnings Response Coefficient.

\subsection{Effects of Profitability on ERC}

The results of this study indicate that profitability has a significant positive effect on ERC $\left(\mathrm{H}_{2}\right.$ received). In Table 3, the average ROA value for the ERC below the 
average has a lower value than the average ROA value for the ERC above the average. This shows that there is a direct relationship between profitability and ERC. This result is following the capital market efficiency theory. Quality information about high profits will get a positive response from investors at the time of the earnings announcement. So, the increase in profits will be followed by an increase in share prices. This is because high profitability shows good company performance. Investor response will certainly increase as there is an increase in company performance.

The results of this study are supported by previous research conducted by Hasanzade (2013), which stated that profitability has a significant and positive influence on the Earnings Response Coefficient. This result is contrary to research conducted by I Gusti (2016), which stated profitability has a negative effect on ERC. The results of this study are also not in line with the results of research conducted by Vinola (2016) and Gunawan (2015), which cannot prove the effect of profitability on Earnings Response Coefficient.

\subsection{Effects of Capital Structure on ERC}

The test results show that the capital structure has no significant effect on ERC $\left(\mathrm{H}_{3}\right.$ is rejected). In Table 3, it can be seen that the difference between the average DER for ERCs below and above the average is relatively small. Thus it indicates that the variable has no significant effect on ERC. Also, the regression coefficient value for the capital structure is positive, so it is also not in accordance with the capital market efficiency theory.

In capital market efficiency theory, good information content will be reflected by an increase in stock prices in response to investors. Low debt composition information is good information that should get a good response from investors. However, the results of this study are unable to prove the significant effect of capital structure on the value of the company's ERC. So it is concluded that the composition of the company's capital is not the main thing that is considered by investors when the company announces earnings. 
The results of this study are in line with research by Gunawan (2015), Hasanzade (2013), and Fitria (2013), revealing the effect of capital structure, which is not significant to the earnings response coefficient. Also, the positive direction of the influence of capital structure on ERC is found in the research conducted by Anggreini (2014). Meanwhile, the results of this study contradict the research of Vinola (2016) and An (2015), who found that capital structure has a significant and negative effect on the earnings response coefficient.

\subsection{Effects of Growth Opportunity on ERC}

The test results show that growth opportunities have a significant effect on ERC ( $\mathrm{H}_{4}$ accepted). In Table 3, the average PBV value for ERC below the average has a higher value than the average PBV value for ERC above the average. This shows that there is an opposite direction between growth opportunity and ERC. Meanwhile, the difference between the average PBV for ERC above and below the average is relatively large enough to indicate that PBV has a significant effect on the ERC value.

One of the objectives of investors to make investments is to develop the capital they have. However, although the results of the study show that growth opportunities are a significant influence on investor response, the direction of the influence of growth opportunities on ERC is the opposite. These results are not in line with the theory. The results of the research show a high growth opportunity that is followed by a decrease in ERC.

Previous studies do not support the results of this study. In research conducted by Hasanzade (2013) and Zakaria (2013), growth opportunities have a significant positive effect on ERC. Meanwhile, this study proves that growth opportunities have a significant negative effect on ERC. The results of this study are also not in line with the results of Gunawan's (2015) and Rahmat's (2016) research, which stated that growth opportunities do not have a significant effect on ERC.

\subsection{Effects of Company Size on ERC}

The test results show that company size has a significant effect on ERC $\left(\mathrm{H}_{5}\right.$ 
accepted). The regression coefficient value for SIZE is positive. In Table 3, it can be seen that the average SIZE for ERC below the average is lower than the average SIZE for ERC above the average. This shows that there is a direct relationship between company size and ERC.

Investors assume companies with large total assets are safer places of investment compared to companies with small total assets. It is because companies with large total assets tend to be more stable during times of crisis. Thus, the size of a large company will be followed by an increase in the value of ERC. Therefore, company size information will have a significant impact on changes in the value of the company's ERC.

The results of this study are in line with research conducted by I Gusti (2016), Mashayekhi (2016), and Zakaria (2013), who found that company size has a significant positive effect on ERC. Meanwhile, these results differ from studies conducted by Gunawan (2015), Zeidi (2014), and Fitria (2013), who found that company size has no significant effect on ERC.

\subsection{Effects of Audit Quality on ERC}

The test results show that audit quality has no significant effect on ERC $\left(\mathrm{H}_{6}\right.$ rejected). In Table 3, it can be seen that the difference between the average AQ for ERC below and above the average is relatively small, thus indicating that the variable has no significant effect on ERC.

Quality audits should get the trust of investors. Investor confidence will be reflected in an increase in stock prices in response to investors. But this research is unable to prove that audit quality has a significant effect on ERC. In this study, audit quality is proxied by the auditor's reputation based on the number of audit clients. Thus, investors in responding to company earnings announcements are not too concerned about whether auditors audit the company with a high or low reputation. In other words, audit quality is not the main determinant of investor response to earnings.

The results of this study are in line with research conducted by Gunawan (2015), which found no significant effect of audit quality on ERC. Meanwhile, the results of 
this study contradict the research undertaken by Fitria (2013), Okolie (2014), Heydari (2015), and Zakaria (2013) that stated that audit quality has a significant effect on earnings response coefficient.

\subsection{Effects of CSR Disclosure on ERC}

The test results show that CSR disclosure has no significant effect on ERC $\left(\mathrm{H}_{7}\right.$ rejected). In Table 3, it can be seen that the difference between CSR averages for ERCs below and above the average is relatively small, thus indicating that the variable has no significant effect on ERC.

Companies that disclose CSR will provide value-added information to investors. In capital market efficiency theory, good information from companies will be reflected in high stock prices in response to that information. But in reality, the wider CSR disclosure by companies does not show a significant increase in ERC. This is because investors prioritize financial performance information rather than corporate social information. Therefore this study shows the results that the effect of CSR disclosure is not significant to ERC.

These results are consistent with research conducted by Dian (2015), which found no significant effect of CSR disclosure on ERC. Also, the negative direction of the influence of CSR on ERC is found in the Vinola (2016) study, which showed that CSR disclosure has a negative effect on ERC.

\subsection{Effects of Conservatism on ERC}

The test results show that conservatism has no significant effect on ERC. These results are not under the hypothesis in this study, so it was concluded that $\mathrm{H}_{8}$ is rejected. In Table 3, it can be seen that the difference between the average KSRV for ERCs below and above the average is relatively small, thus indicating that the variable has no significant effect on ERC.

The more a company is careful about reporting earnings, the better the investor's response should be, as seen from the increase in ERC. But researchers found no significant effect of conservatism on ERC. The use of conservatism principles in 
companies is not the main factor influencing investors' decisions to invest. This is possible because investors prefer companies that provide information about the actual financial condition. So it is concluded that the use of the conservatism principle would not give much change to the ERC value of manufacturing companies.

The results show that conservatism has no significant effect on ERC is not supported by previous researches. However, the negative direction of conservatism towards ERC is as found by Zeidi (2014), which stated that there is a significant negative influence between conservatism and ERC. But it is different from Arna's research (2016) that found that conservatism has a positive effect on the earnings response coefficient.

\section{Conclusions, Implications, Limitations, and Suggestions}

The results show that profitability and company size has a significant positive effect on ERC. The results also show that earnings persistence and growth opportunities have a significant negative effect on ERC. Meanwhile, capital structure, audit quality, CSR disclosure, and conservatism have an insignificant influence on ERC.

This research theory implies that ERC is a measurement of company earnings informativeness that explains how the market will respond to the announced earnings value of the company. So, in this case, earnings informativeness will be more determined from factors, namely earnings persistence, profitability, growth opportunity, and company size.

The practical implication of this research is that investors in analyzing and understanding earnings information need to consider earnings persistence, profitability, growth opportunities, and company size. Also, companies need to pay attention to these four factors because these factors have a significant influence on investor responses to announced earnings.

Limitations of this study include (1) The existence of outlier data in this study that must be excluded because it causes the testing of the classical assumptions of 
normality are not met. Outlier data were found quite a lot, so the number of samples in this study also decreased a lot. (2) The measurement of CSR disclosure is based on the researchers' assumptions, so there is a possibility that the subjectivity of the researcher influences CSR disclosure. (3) Data collection in this study cannot be carried out optimally because several companies do not publish quarterly and annual reports.

Suggestions for future research are to consider the use of moderation variables to see whether the influence of independent variables on ERC can be strengthened or weakened by the presence of other variables. Future studies can add independent variables that are not used in this study, such as systematic risk. Also, subsequent research can develop from this research by using samples from sectors other than manufacturing, for example, from the banking industry or other non-manufacturing industries, and the results can be compared between sectors.

\section{REFERENCES}

An, Yohan. 2015. "Earnings Response Coefficient and Default Risk: Case of Korean Firms". International Journal of Financial Research. Vol 6. No 2. Pp 67-71

Anggreni Dian Kurniawati. 2014. "Pengaruh Karakteristik Perusahaan terhadap Earnings Response Coefficient”. Jurnal Akuntansi Bisnis. Vol 13. No 25. Pp 1-24

Arna Suryani. 2016. "Financial Statements Conservatism Effect on Earnings Response Coefficient and Earning Management". International Journal of Economics and Research. Vol 13. No 8. Pp. 3625-3634

Bhattacharya, Sudipto. 1979. "Imperfect Information, Dividend Policy, and The Bird In The Hand Fallacy". Vol 10. No 1. Pp 259-270

Dian Masita Dewi. 2015. "The Role of CSRD on Company's Financial Performance and Earnings Response Coefficient”. Procedia Social and Behavioural Science 211. Pp 541549

Du, Jun., Zhao., Gaogang. 2014. "Big N Auditors and Earnings Response Coefficients - A Comparison Study between the US and China". China Accounting and Finance Review. Vol.16. No.2. Pp. 183-201

Fitria Pranandari., Zaenal Fanani., Khusnul Prasetyo., dan Agus Widodo Mardijuwono. 2013. "Meta-Analysis: a Decade Study about the Determinants of Earnings Response Coefficient (ERC) in Indonesia". Simposium Nasional Akuntansi XVI. 
Gunawan Santoso. 2015. "Determinan Koefisien Respon Laba". Jurnal Parsimonia. Vol 2. No 2. Pp 69-85

Hasanzade, Mahboobe., Darabi, Roya., dan Mahfoozi, Gholamreza. 2013. "Factors Affecting the Earnings Response Coefficient: An Empirical study for Iran". Journal of Natural and Social Science. Vol 2. No 3. Pp 2551-2560

Heydari, Imam. 2015. "Investigating Relationship between Audit Quality and Earnings Response Coefficient of Listed Firms in Tehran Stock Exchange". Research Journal of Finance and Accounting. Vol 6. No. 5. Pp 80-89

I Gusti Ayu Ratih Permata Dewi, I Ketut Yadnyana,šepi Putu Sudana. 2016. "Pengaruh Profitabilitas dan Ukuran Perusahaan terhadap Ketepatwaktuan Penyampaian Laporan Keuangan dan Implikasinya pada Earnings Response Coefficient”. Jurnal Ekonomi dan Bisnis Universitas Udayana. Vol 5. No 9. Pp 3031-3056

Luciana Spica Almilia. 2004. “Analisis Faktor-Faktor Yang Mempengaruhi Kondisi Financial Distress Suatu Perusahaan Yang Terdaftar di Bursa Efek Jakarta". Jurnal Riset Akuntansi Indonesia. Vol 7. No 1

Mashayekhi, Bita., Aghel, Zaynab Lotfi. 2016. "A Study on Determinants of Earnings Response Coefficient in Emerging Market". International Journal of Social, Behavioral, Educational, Economic, Business, and Industrial Engineering. Vol 10. No 7. Pp 2454-2457

Okolie, Augustine O. 2014. "Audit Quality and Earnings Response Coefficients of Quoted Companies in Nigeria". Journal of Applied Finance \& Banking. Vol 4. No 2. Pp. 139161

Rahmat Syarifulloh., Agus Wahyudin. 2016. "Determinan Koefisien Respon Laba". Accounting Analysis Journal. Vol 5. No 1. Pp 79-87

Scott, William. 2012. Financial Accounting Theory. Toronto: Prentice-Hall.

Zakaria, Nor Balkish., Azwan, Mohamad., Abidin, Rabiatul Alawiyah Zainal. 2013. "Default Risk and Earnings Response Coefficient. Evidence from Malaysia". Journal of Basic and Applied Scientific Research. Vol 3. No 6. Pp 535-545

Zakaria, Nor Balkish., dan Daud, Dalila. 2013. "Does Big 4 Affect the Earnings Response Coefficient(ERC)? Evidence From Malaysia". Journal of Modern Accounting and Auditing. Vol 9. No 9. Pp 1204-1215.

Zeidi, Abbas R., Taheri, Zabihollah., Farahabadi, Ommolbanin Gholami. 2014. "The Conservatism in Accounting and Its Effect on Earnings Response Coefficient in Tehran Stock Exchange Listed Companies". International Journal of Scientific Research in Knowledge. Vol 2. No 1. Pp. 28-37 